\title{
Pengukuran Radiasi Elektromagnetik Frekuensi Sangat Tinggi (VHF) Petir Compact Intracloud Discharges
}

\author{
Primas Emeraldi* dan Ariadi Hazmi \\ Jurusan Teknik Elektro, Fakultas Teknik, Universitas Andalas \\ *Corresponding author, e-mail: primasemeraldi@ ft.unand.ac.id
}

\begin{abstract}
Abstrak - Disamping jenis petir intracloud biasa, ada jenis lain dari petir intracloud yang dikenal sebagai Compact Intracloud Discharges (CIDs). CIDs memancarkan radiasi frekuensi tinggi yang kuat dibandingkan dengan sambaran balik pertama dari petir awan ke tanah ataupun jenis pelepasan muatan di awan lainnya. Radiasi frekuensi tinggi dari petir CIDs ini dapat mempengaruhi sistem elektronik sehingga dapat menimbulkan bahaya jika mengenai peralatan komunikasi, radio, satelit dan sistem avionik. Dalam makalah ini disajikan perancangan detektor petir medan listrik cepat untuk mendeteksi medan radiasi pita lebar dari petir CIDs dan detektor medan listrik Very High Frequency (VHF) untuk mendeteksi radiasi frekuemsi tinggi dari petir tersebut. Rangkaian detektor medan listrik cepat terdiri dari rangkaian buffer dan integrator amplifier sedangkan detektor medan listrik VHF berupa rangkaian buffer dan active band pass filter dengan konfigurasi multiple feed back (MFB) yang mempunyai frekuensi tengah 51,76 MHz. Dari pengukuran medan listrik petir selama bulan Maret 2016 sampai Maret 2017 diperoleh sebanyak 104 data petir CID negatif dan 33 data petir CID positif beserta gelombang radiasi VHF nya. Gelombang medan listrik radiasi VHF dari petir CID terdeteksi bersamaan dengan terjadinya kejadian petir CID. Radiasi VHF petir CID negatif dan petir CID positif mempunyai karakteristik waktu yang relatif sama.
\end{abstract}

\section{Kata Kunci : Petir, Compact Intracloud Discharges, Detektor Medan Listrik, Band Pass Filter}

\begin{abstract}
Compact Intracloud Discharges (CIDs) are another type of intracloud lightning. CIDs emit strong high-frequency emissions compared to the first return stroke from cloud to ground lightning or other types of discharge in clouds. High-frequency radiation from lightning CIDs may affect electronic systems, which may pose a danger to communications equipment, radio, satellite and avionics systems. This paper presents a design of a fast electric field detector to detect a broadband of radiation from CIDs and Very High Frequency (VHF) electric field detector to detect high-frequency radiation of CIDs. Fast electric field detector circuit consists of buffer circuit and integrator amplifier while VHF electric field detector is a buffer circuit and active band pass filter at $51.76 \mathrm{MHz}$. From the measurement of the electric field of lightning during March 2016 to March 2017, 104 CID negative lightning data and 33 positive CID lightning data was recorded. VHF radiation of CID is detected simultaneously with the occurrence of CID lightning events. The VHF radiation of negative CID and positive CID have similar time characteristics.
\end{abstract}

Keywords : Lightning, Compact Intracloud Discharges, Electric Field Detector, Band Pass Filter

\section{Pendahuluan}

Petir dapat dibagi menjadi dua jenis utama yaitu, petir awan ke tanah dan petir diawan. Saat petir menyambar tanah atau benda yang ada di permukaan tanah, itu disebut petir awan ke tanah (Cloud to Ground). Jika pelepasan muatan terjadi di dalam awan atau di antara awan maka disebut sebagai petir diawan (Intracloud). Petir jenis intracloud ini adalah yang paling umum dari semua jenis petir dengan persentase kejadian yang lebih banyak. Disamping jenis petir intracloud biasa, ada jenis lain dari petir intracloud yang dikenal sebagai Compact Intracloud Discharges (CIDs) atau juga disebut Narrow Bipolar Pulses (NBPs) [1-8].

CIDs adalah tipe lain dari pulsa kegagalan awal (initial breakdown) dari petir yang terjadi di awan. CIDs berupa pulsa bipolar tunggal dengan amplitudo yang besar, yang biasanya memiliki durasi dari 10 sampai $30 \mu$ s dan waktu naik (rise time) pulsa yang sangat cepat berkisar $1 \mu \mathrm{s}$ [1-8] Pulsa CIDs sangat unik, berbeda dengan bentuk pulsa peluahan petir lainnya. Pulsa CIDs dihasilkan oleh momen arus besar dan memancarkan radiasi frekuensi radio yang kuat 
pada frekuensi beberapa MHz. Mekanisme produksi CIDs masih misterius. Pulsa CIDs dapat berupa pulsa positif atau pulsa negatif. Menurut distribusi ketianggian muatan dan polaritas muatan di awan, CID positif dihasilkan akibat peluahan muatan antara lapisan muatan negatif utama dan lapisan muatan positif atas $(8-16 \mathrm{~km})$ sedangkan CID negatif dihasilkan akibat peluahan muatan antara lapisan muatan positif atas dan lapisan negatif di bagian atas awan. (16$19 \mathrm{~km})[4]$.

CIDs memancarkan emisi frekuensi tinggi yang kuat dibandingkan dengan sambaran balik pertama dari petir awan ketanah ataupun jenis pelepasan muatan di awan lainnya. Radiasi frekuensi tinggi dari petir CIDs ini dapat mempengaruhi sistem elektronik sehingga dapat menimbulkan bahaya jika mengenai peralatan komunikasi, radio, TV, satelit dan sistem avionik. Dengan menggunakan informasi dari radiasi frekuensi tinggi pada saat pelepasan muatan petir, proteksi petir yang lebih baik untuk sistem di atas dapat dikembangkan.

Banyak informasi bermanfaat dapat diperoleh dengan menganalisis medan radiasi pita lebar (broad band) dan medan radiasi pita sempit (narrow band) yang dihasilkan oleh petir. Dalam makalah ini disajikan perancangan detektor petir medan listrik cepat untuk mendeteksi medan radiasi pita lebar dari petir CIDs dan detektor medan listrik Very High Frequency (VHF) untuk mendeteksi radiasi frekuensi tinggi petir CIDs tersebut. Detektor petir yang dirancang digunakan dalam pengukuran medan listrik petir beserta radiasi VHF nya.

\section{Tinjauan Pustaka}

Radiasi elektromagnetik dari petir mempunyai ciri frekuensi pita lebar (broadband) dalam rentang $\mathrm{kHz}$ sampai GHz. Radiasi frekuensi tinggi dari petir penting untuk dipahami karena mampu memberikan gangguan kepada perangkat elektronik saat terjadinya samparan petir. Emisi elektromagnetik petir ini bersifat impulsif dengan amplitudo yang dapat memberikan potensi bahaya pada sistem yang sensitif terhadap medan transien.

Beberapa kajian telah dilakukan terhadap emisi elektromagnetik yang dihasilkan oleh petir pada rentang frekuensi Ultra High Frequency (UHF) dan Very High Frequency (VHF). Le Vine dan Krider [9] melaporkan variasi karakteristik waktu gelombang radiasi frekuensi tinggi sambaran balik pertama dan sambaran balik berikutnya dari petir awan ke tanah pada beberapa pita frekuensi $3 \mathrm{MHz}, 30 \mathrm{MHz}, 129 \mathrm{MHz}$ dan 295 MHz. Clegg dan Thomson [10] melaporkan radiasi frekuensi tinggi pada pita frekuensi 10 MHz yang dikaitkan dengan petir dalam awan dan petir awan ke tanah.

Kajian terhadap emisi elektromagnetik frekuensi tinggi oleh petir CIDs masih sedikit dibandingkan dengan jenis petir dalam awan ataupun petir awan ke tanah. Durasi rata-rata emisi elektromagnetik frekuensi tinggi $(3 \mathrm{MHz}$ sampai $30 \mathrm{MHz}$ ) yang terkait dengan CIDs adalah 2,8 $\mu$ s dan amplitudo 10 kali lebih besar daripada emisi elektromagnetik oleh petir dalam awan atau pun oleh sambaran balik pertama petir awan ke tanah [2]. Emisi elektromagnetik yang kuat dihasilkan oleh petir CIDs adalah $30 \mathrm{~dB}$ lebih kuat daripada jenis petir lainnya pada awan yang sama [7].

Pengukuran intensitas medan listrik pada saat sambaran petir dapat dilakukan dengan menggunakan antena pelat. Intensitas medan listrik di permukaan tanah pada dapat diukur sebagai fungsi waktu dengan mengukur tegangan listrik antara antena pelat dan ground. Bila rangkaian pengukuran dilekatkan pada antena, tegangan keluaran $(v)$ seperti yang digambarkan pada gambar 1 akan bergantung pada nilai konstanta waktu peluruhan yaitu nilai RC dari rangkaian [11]. Jika RC bernilai tak hingga maka tegangan output akan persis dengan tegangan penggeraknya yaitu intensitas medan listrik yang mengenai antena. Dalam hal ini tegangan output memiliki perkembangan temporal yang sama dengan medan listrik yang mengenai antena pelat.

Pengukuran medan listrik petir menggunakan passive integrator seperti yang ditunjukan pada gambar 1 dimana rangkaian RC terhubung langsung dengan alat ukur (osiloskop) menyebabkan konstatanta waktu dari rangkaian akan terpengaruh oleh impedansi alat ukur. Rangkaian yang lebih umum digunakan adalah rangkaian active integrator menggunakan op-amp yang dihubungkan ke antena pelat seperti yang ditunjukan pada gambar 2. Pengukuran dengan rangkaian active integrator akan mempunyai konstanta waktu yang hanya bergantung pada nilai $\mathrm{R}$ dan $\mathrm{C}$ [12-13]. 


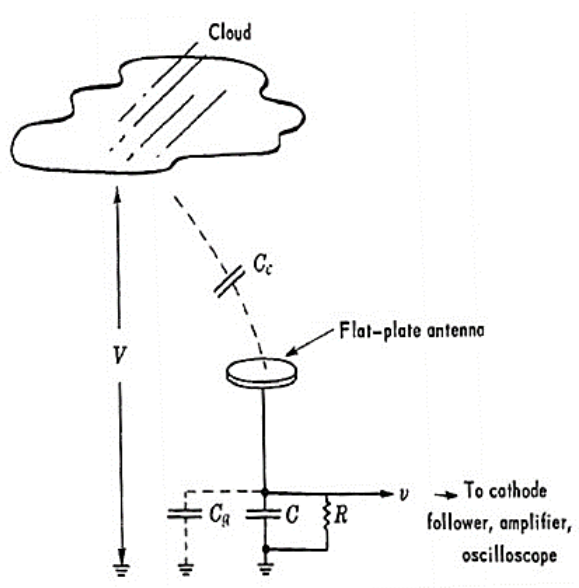

Gambar 1. Antena Pelat dengan Rangkaian $\mathrm{RC}$ [11]

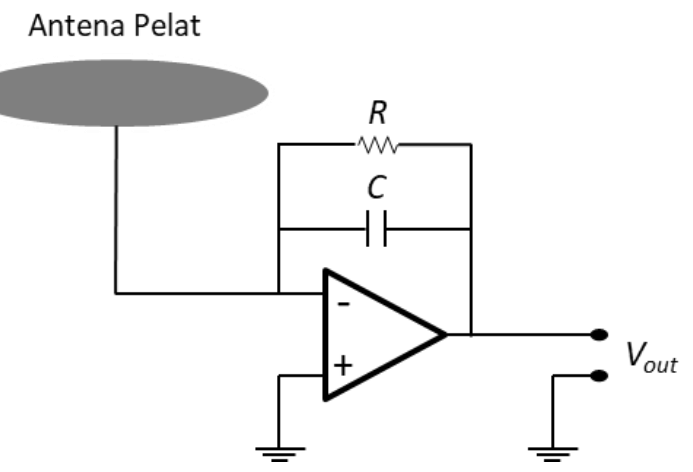

Gambar 2. Antena Pelat dengan Rangkaian active integrator [12-13]

Muatan $(Q)$ yang terinduksi pada antena pelat ditunjukan pada persamaan (1)

$$
Q=\varepsilon_{0} E A
$$

dimana $\varepsilon_{0}$ adalah permitivitas ruang hampa $(8,85$ $\left.\mathrm{x} 10^{-12} \mathrm{~F} / \mathrm{m}\right), \mathrm{E}$ adalah intensitas medan listrik $(\mathrm{V} / \mathrm{m})$ dan A adalah luas antena pelat. Perubahan medan listrik akan menyebabkan muatan pada antena pelat akan bergerak dan mengakibatkan mengalir arus (I) pada peramaan (2). Arus (I) mengalir ke rangkaian integrator yang menghasilkan tegangan keluaran rangkaian integrator $\left(\mathrm{V}_{\text {out }}\right.$ ) pada persamaan (3) dimana $\mathrm{C}$ adalah kapasitansi dari kapasitor pada rangkaian integrator.

$$
I=\frac{d Q}{d t}=\varepsilon_{0} A \frac{d E}{d t}
$$

$$
V_{\text {out }}=\frac{\varepsilon_{0} A E(t)}{C}
$$

\section{Perancangan Detektor Petir}

Sistem pengukuran medan listrik petir yang dirancang terdiri dari dua komponen utama yaitu detektor perubahan medan listrik cepat dan detektor medan listrik VHF. Detektor perubahan medan listrik cepat digunakan untuk merekam pulsa medan listrik petir CIDs sedangkan radiasi VHF dari pulsa CIDs tersebut direkam menggunakan detektor medan listrik VHF.

\subsection{Detektor Medan Listrik Cepat}

Detektor medan listrik cepat menggunakan antena pelat datar untuk mendeteksi sinyal dari medan listrik vertikal yang dihasilkan oleh peluahan muatan saat terjadi petir. Antenna pelat datar menggunakan material stainless stell berbentuk lingkaran dengan diameter $30 \mathrm{~cm}$ dan ketebalan $5 \mathrm{~mm}$ seperti yang ditunjukan pada gambar 3. Rangkaian detektor medan listrik cepat terdiri dari rangkaian buffer dan integrator amplifier. Rangkaian buffer menggunakan IC high speed buffer LMH6559 yang berfungsi untuk menyesuaikan impedansi antenna yang bernilai besar dengan impedansi rangkaian intergrator amplifier.

Keluaran rangkaian buffer dihubungkan ke input rangkaian integrator amplifier. Rangkaian integrator amplifier yang dirancang mempunyai konstanta time delay $10 \mathrm{~ms}$ menggunakan IC opamp LMH6609 dengan nilai kapasitor $1 \mathrm{nF}$ dan resistor $10 \mathrm{M} \Omega$. Skema rangkaian buffer beserta integrator amplifier ditunjukan pada gambar 4 .

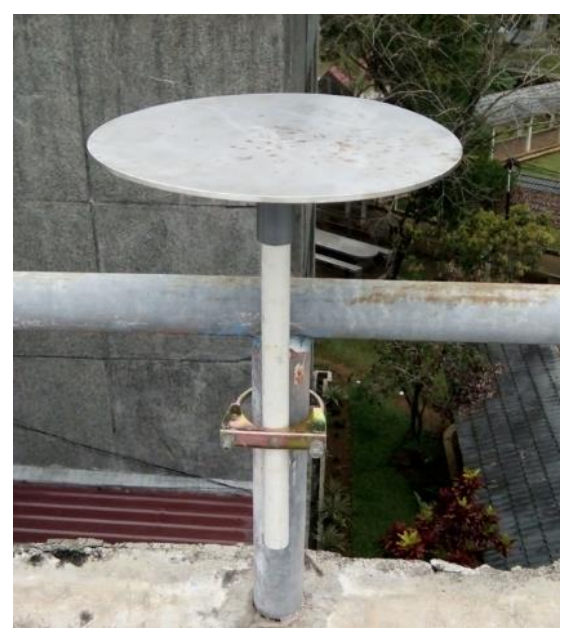

Gambar 3. Antena pelat datar 


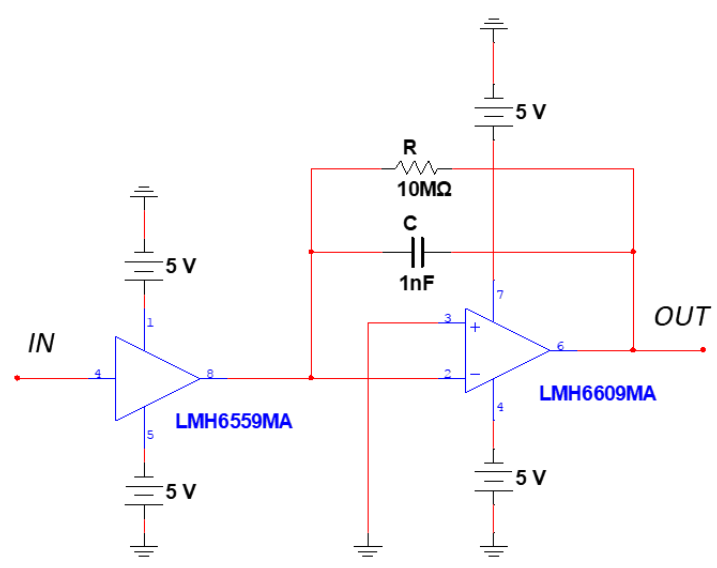

Gambar 4. Rangkaian Buffer dan Integrator Amplifier

\subsection{Detektor Medan Listrik VHF}

Antenna pelat datar juga digunakan pada detektor medan listrik VHF. Detektor medan listrik VHF terdiri dari rangkaian buffer dan active band pass filter (BPF). Rangkaian buffer yang digunakan sama dengan yang digunakan pada rangkaian detektor medan listrik cepat. Band pass filter dirancang mempunyai frekuensi tengah $50 \mathrm{MHz}$. Rangkaian BPF yang dirancang berupa active band pass filter sehingga mempunyai gain menggunakan op-amp dengan konfigurasi multiple feed back (MFB). Gambar 5 menunjukan skematik dari rangkaian BPF yang digunakan. Op-amp yang digunakan pada rangkaian BPF adalah IC op-amp LMH6609.

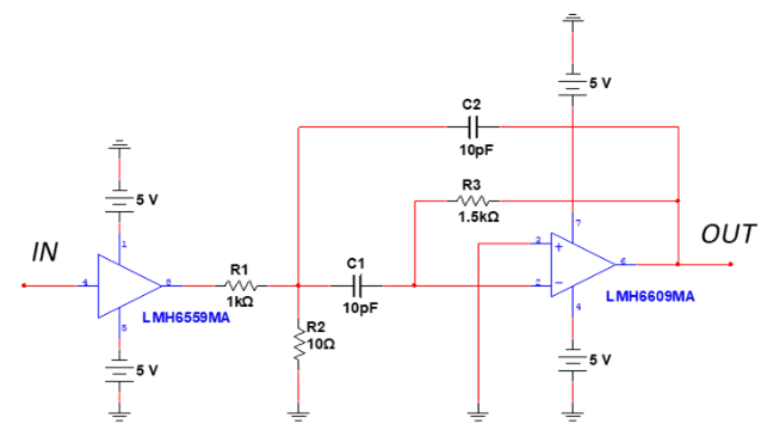

Gambar 5. Rangkaian Buffer dan BPF

\section{Hasil dan Pembahasan}

Rangkaian detektor medan listrik cepat dan detektor VHF disimulasikan untuk mengetahui respon frekuensinya. Hasil simulasi respon frekuensi rangkaian detektor medan listrik cepat ditunjukan pada gambar 6 sedangkan respon frekuensi rangkaian detektor medan listrik VHF ditunjukan pada gambar 7 .
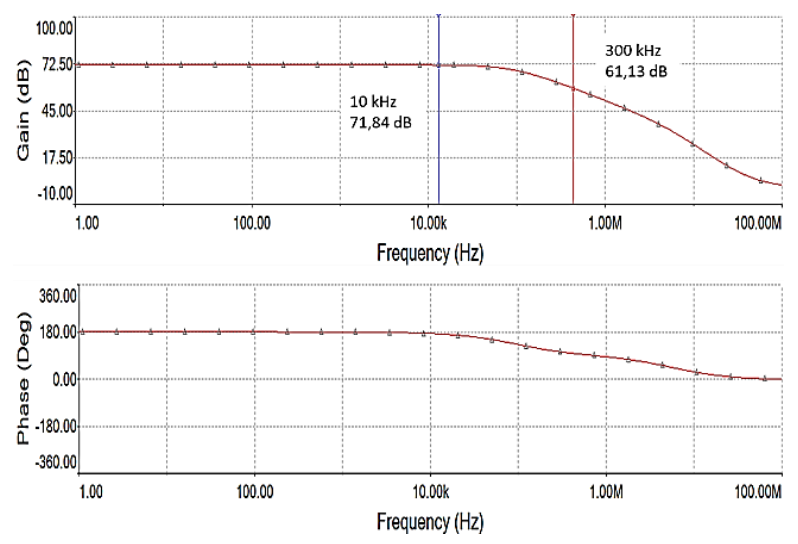

Gambar 6. Respon Frekuensi Rangkaian Buffer dan Integrator Amplifier
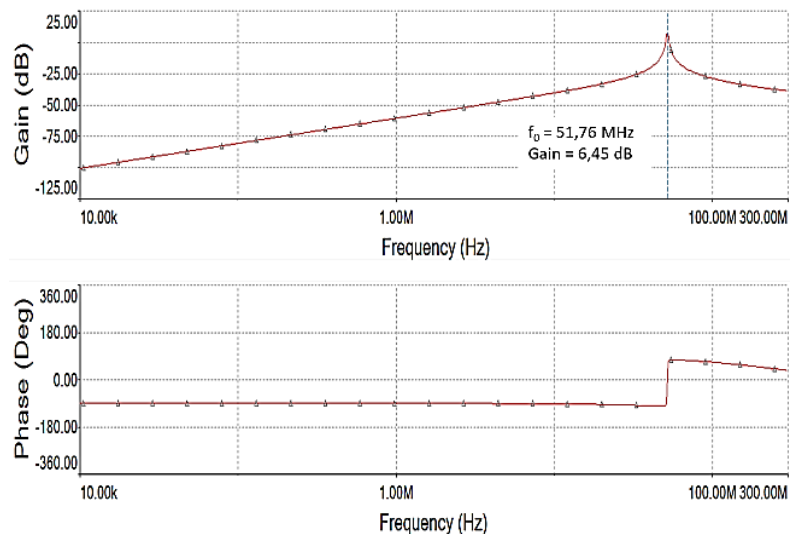

Gambar 7. Respon Frekuensi Rangkaian Band Pass Filter

Hasil simulasi respon frekuensi memperlihatkan rangkaian buffer dan integrator amplifier mempunyai gain konstan dengan nilai 71,84 dB pada bandwidth yang sangat lebar (broadband) yaitu dari frekuensi rendah sampai $10 \mathrm{kHz}$ dan mempunyai gain $61,13 \mathrm{~dB}$ pada frekuensi $300 \mathrm{kHz}$. Respon frekuensi ini menunjukan bahwa rangkaian buffer dan integrator amplifier yang dirancang sesuai digunakan sebagai detektor medan listrik cepat untuk mengukur radiasi medan listrik petir broadband.

Simulasi respon frekuensi juga memperlihatkan bahwa rangkaian buffer dan integrator amplifier mempunyai bandwidth yang sangat sempit (narrow band) dengan frekuensi tengah adalah $51.76 \mathrm{MHz}$ yang sedikit berbeda 
dari target rancangan yaitu $50 \mathrm{MHz}$ dikarenakan pemilihan nilai komponen resistor dan kapasitor yang disesuaikan dengan nilai tersedia dipasaran sehingga mudah diimplementasikan. Berdasarkan hasil respon frekuensi tersebut disimpulkan bahwa rangkaian band pass yang dirancang sesuai untuk pengukuran medan listrik petir pada rentang VHF.

Rangkaian detektor VHF hasil rancangan kemudian diuji respon impuls nya dengan menerapkan sinyal impuls dari fuction generator dan diamati sinyal keluarannya melalui osiloskop. Respon impuls dari detektor VHF diperlihatkan pada Gambar 8.
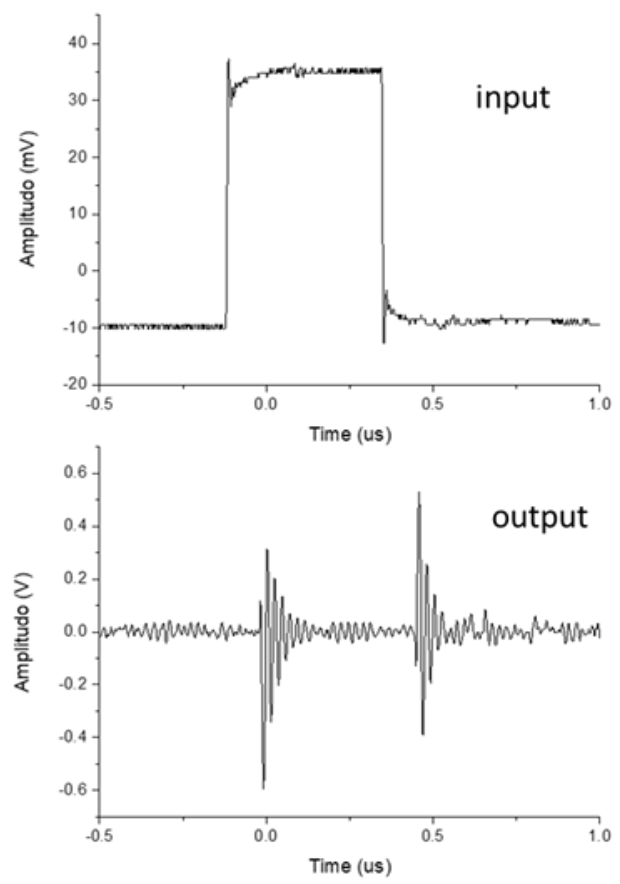

Gambar 8. Respon Impuls Rangkaian Band Pass Filter

Detektor medan listrik cepat dan detektor medan listrik VHF diterapkan pada sistem pengukuran medan listrik petir. Sistem pengukuran ini berada pada gedung jurusan teknik elektro Universitas Andalas pada ketinggian $317 \mathrm{~m}$ di atas permukaan laut. Sistem pengukuran medan listrik petir ditunjukan pada gambar 9. Sinyal keluaran rangkaian detektor medan listrik cepat dan detektor medan listrik VHF dihubungkan ke picoscope (3406D) yang berfungsi sebagai penyimpan data. Picoscope dioperasikan dengan sampling rate $500 \mathrm{Ms} / \mathrm{s}$. Sinyal keluaran rangkaian BPF dimasukan ke picoscope (3406D) yang sama dengan detektor medan listrik cepat.

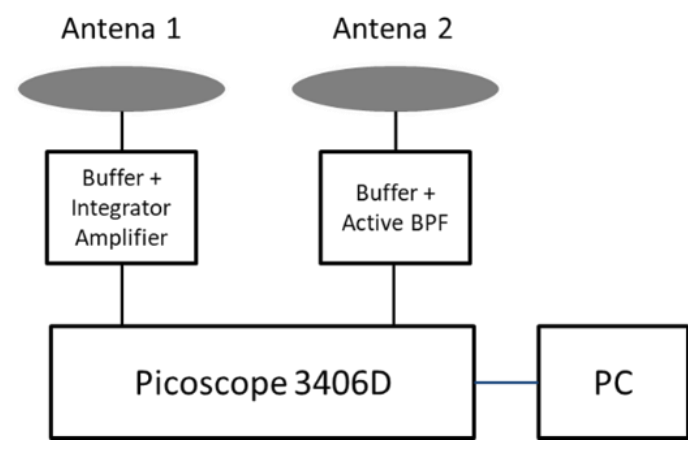

Gambar 9. Skema Pengukuran Gelombang Medan Listrik Petir

Dari hasil pengukuran medan listrik petir selama bulan Maret 2016 sampai Maret 2017 diperoleh sebanyak 137 data gelombang medan listrik petir NBE beserta gelombang radiasi VHF nya. 104 data berupa data petir CID negatif dan 33 data berupa data petir CID positif. Bentuk gelombang petir CID negatif dan petir CID positif beserta gelombang radiasi VHF nya ditunjukan pada gambar 10 dan gambar 11.

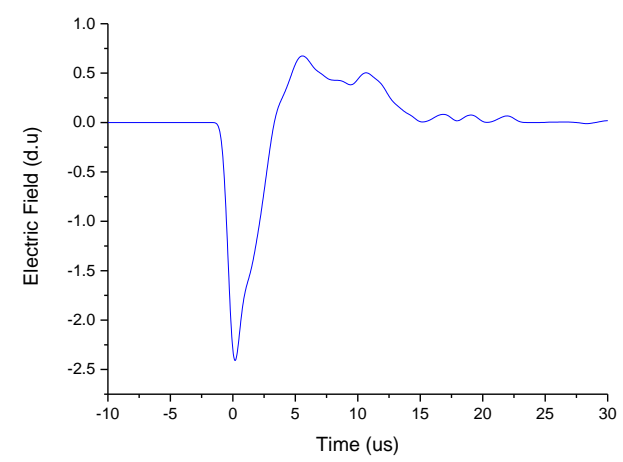

(a)

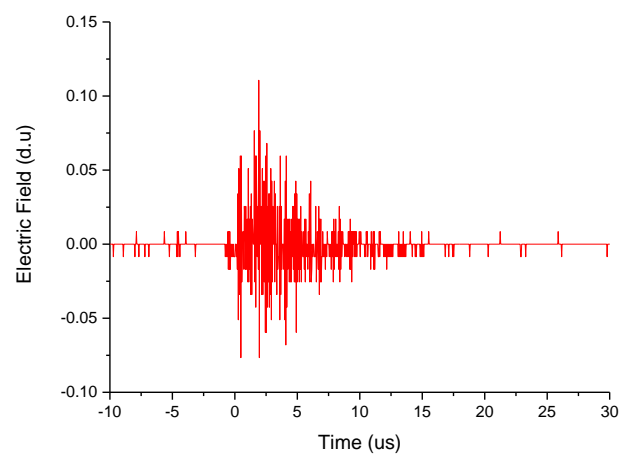

(b)

Gambar 10. (a) Bentuk Gelombang Pulsa Petir CID Negatif beserta (b) emisi VHF 


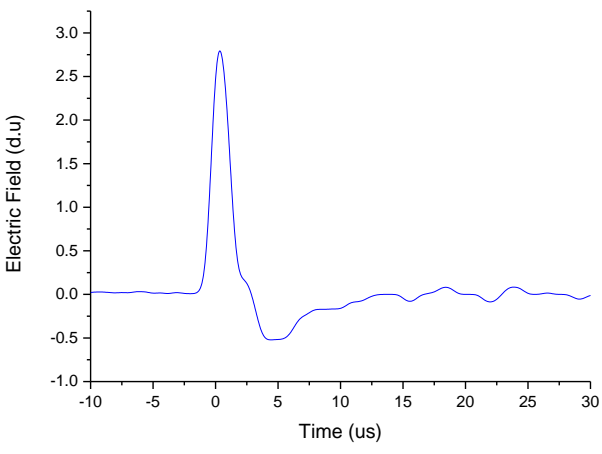

(a)

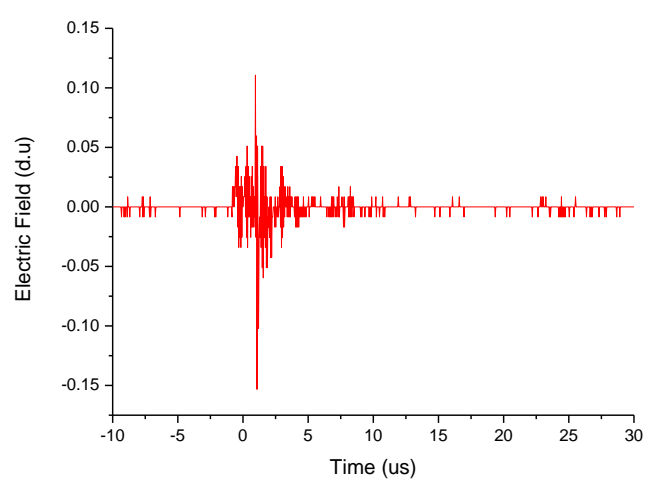

(b)

Gambar 11. (a) Bentuk Gelombang Pulsa Petir CID Positif beserta (b) emisi VHF

\section{Kesimpulan}

Detektor medan listrik cepat mempunyai mempunyai lebar pita (bandwidth) sangat lebar (broadband) dengan gain konstan 71,84 $\mathrm{dB}$ dari frekuensi rendah sampai $10 \mathrm{kHz}$ dan mempunyai gain $61,13 \mathrm{~dB}$ pada frekuensi $300 \mathrm{kHz}$. Sedangkan detektor VHF mempunyai lebar pita yang sempit (narrowband) dengan frekuensi tengah $51.76 \mathrm{MHz}$. Detektor medan listrik cepat dan detektor medan listrik VHF berhasil diimplementasikan pada pengukuran medan listrik petir CIDs beserta radiasi VHFnya.

Gelombang medan listrik radiasi VHF dari petir CIDs terdeteksi bersamaan dengan terjadinya kejadian petir CIDs. Radiasi VHF petir CID negatif dan petir CID positif mempunyai karakteristik waktu yang relatif sama.

\section{Ucapan Terima Kasih}

Penelitian ini didukung oleh penelitian dosen Jurusan Teknik Elektro Fakultas Teknik Universitas Andalas dengan nomor kontrak 096/UN.16.09.D/PL/2017.

\section{Daftar Pustaka}

[1] Le Vine, D. M., "Source of the strongest RF radiation from lightning," Journal of Geophysical Research, 85, 1980.

[2] Smith, D.A., Shao, X.M., Holden, D.N., Rhodes, C.T., Brook, M., Krehbiel, P.R., Stanley, M., Rison, W., Thomas, R.J., "A distinct class of isolated intracloud lightning discharges and their associated radio emissions," Journal of Geophysical Research. 104, 1999.

[3] Eack, K.B., "Electrical characteristics of narrow bipolar events," Geophysical Research Letters, 31, L20102, 2004.

[4] Wu, T., W. Dong, Y. Zhang, T. Funaki, S. Yoshida, T. Morimoto, T. Ushio and Z. Kawasaki, "Discharge height of lightning narrow bipolar events," Journal of Geophysical Research, Vol. 117, D05119, 2012.

[5] Wu, T., W. Dong, Y. Zhang, and T. Wang, "Comparison of positive and negative compact intracloud discharges," Journal of Geophysical Research, 116, 2011.

[6] Rison, W., P. R. Krehbiel, M. G. Stock, H. E. Edens, Shao, X., R. J. Thomas, M. A. Stanley, and Zhang, Y., "Observations of narrow bipolar events reveal how lightning is initiated in thunderstorms," Nature Communications, 7:10721, 2016.

[7] Nag, A., and V. A. Rakov, "Compact intracloud lightning discharges: 1. Mechanism of electromagnetic radiation and modeling," Journal of Geophysical Research, 115, 2010.

[8] Hazmi, A., Emeraldi, P., Hamid., M.I., Takagi, N., "Research on positive narrow bipolar events in padang," Int. Conf. on Information Tech., Computer, and Electrical Engineering (ICITACEE), Oct 19-21 st, 2016, Semarang, Indonesia, 2016.

[9] Le Vine, D.M., Krider, E.P., "The temporal structures of HF and VHF radiations during Florida lightning return strokes," 
Geophysical Research Letters, vol. 4 (1), 13 - 16. 1977.

[10] Clegg, R.J. and Thomson, E.M., "Some properties of EM radiation from lightning," Journal of Geophysical Research, vol. 84 (C2), $719-724.1979$.

[11] Cooray, V., Lundquist, S., "Characteristics of the radiation fields from lightning in Sri Lanka in the tropics," Journal of Geophysical Research, vol. 90, 6099 6109. 1985.

[12] Hazmi, A., Emeraldi, P., Hamid., M.I., Takagi, N., "Some characteristics of multiple stroke negative cloud to ground lightning flashes in Padang", International Journal on Electrical Engineering and Informatics, Volume 8, Number 2, 438450, 2016.

[13] Emeraldi, P., Hazmi, A., "Karakteristik Medan Listrik Atmosfer Kota Padang dan Hubungannya Dengan Sambaran Petir Awan ke Tanah," Jurnal Nasional Teknik Elektro, Vol. 6 No.1, 2017.

\section{Biodata Penulis}

Primas Emeraldi, menerima gelar sarjana Teknik Elektro dari Universitas Andalas pada tahun 2009 dan gelar Magister Teknik Elektro dan Institut Teknologi Bandung pada tahun 2013. Sejak tahun 2015 menjadi pengajar pada Jurusan Teknik Elektro Universitas Andalas. Bidang penelitian yang diminati adalah deteksi petir dan aplikasi plasma.

Ariadi Hazmi, menerima gelar sarjana Teknik Elektro dari Universitas Sriwijaya pada tahun 2009, gelar Magister Teknik Elektro dari Institut Teknologi Bandung pada tahun 2002 dan gelar Dr. Eng dari Gifu University pada tahun 2008. Sejak tahun 1999 menjadi pengajar pada Jurusan Teknik Elektro Universitas Andalas. Bidang penelitian yang diminati adalah plasma dan proteksi petir. Merupakan anggota dari The Society of Atmospheric Electricity of Japan. 